\title{
POTENSI REKRUT IKAN BONTI-BONTI (Paratherina striata Aurich) DI DANAU TOWUTI, SULAWESI SELATAN
}

\author{
Syahroma Husni Nasution ${ }^{1)}$, Ismudi Muschsin ${ }^{2)}$, dan Sulistiono2) \\ 1)Peneliti pada Pusat Penelitian Limnologi-Lembaga IImu Pengetahuan Indonesia, Cibinong-Bogor \\ ${ }^{2}$ Staf Pengajar pada Fakultas Perikanan dan IImu Kelautan-Institut Pertanian Bogor, Bogor \\ Teregistrasi I tanggal: 5 Maret 2010; Diterima setelah perbaikan tanggal: 16 Maret 2010; \\ Disetujui terbit tanggal: 26 Maret 2010
}

\begin{abstract}
ABSTRAK
Ikan bonti-bonti (Paratherina striata) selain endemik, statusnya tergolong rawan punah (vulnerable species) dan hanya terdapat di Danau Towuti dan Danau Mahalona. Masyarakat di sekitar danau memanfaatkan ikan ini sebagai ikan konsumsi, ikan hias, dan bahan pakan hewan. Populasi ikan ini dikhawatirkan mengalami penurunan, diduga karena degradasi kualitas lingkungan dan penangkapan ikan yang cenderung intensif. Penelitian ini bertujuan untuk mengkaji potensi rekrut ikan bonti-bonti sebagai dasar pengelolaannya. Pengamatan dilakukan di Danau Towuti setiap bulan selama 12 bulan dari bulan Mei 2006-April 2007. Contoh ikan diperoleh menggunakan jaring insang eksperimental dengan ukuran mata jaring 0,625, 0,75, 1,0, dan 1,25 inci yang dioperasikan di lima stasiun (Tanjung Bakara; inlet Danau Towuti; Pulau Loeha; outlet Danau Towuti dan Beau). Potensi rekrut ikan dapat dilihat dari nisbah kelamin, diameter telur, fekunditas, dan indeks kematangan gonad. Hasil penelitian memperlihatkan bahwa nisbah kelamin total ikan bonti-bonti jantan dan betina 1,0:0,9. Fekunditas ikan bonti-bonti 818-6.051 butir. Diameter telur ikan bonti-bonti berkisar antara 0,01-1,50 mm. Nilai indeks kematangan gonad ikan bonti-bonti jantan dan betina paling tinggi dijumpai di stasiun II, masing-masing 3,96 dan 6,77\%. Ditinjau dari fekunditas, potensi rekrut ikan bonti-bonti lebih tinggi dibandingkan ikan Telmatherinidae lain. Secara temporal, nilai rata-rata indeks kematangan gonad tertinggi pada ikan jantan terjadi pada bulan Mei dan Nopember dengan nilai $2,09 \pm 1,36 \%$ dan $1,85 \pm 1,06 \%$, demikian pula pada ikan betina dengan nilai $3,39 \pm 1,47$ dan $3,47 \pm 1,37 \%$. Rekruitmen ikan bonti-bonti terjadi setiap bulan dengan periode tertinggi antara bulan Oktober-Nopember.
\end{abstract}

\section{KATA KUNCI: potensi rekrut, nisbah kelamin, fekunditas, Paratherina striata, Danau Towuti}

ABSTRACT: Recruitment potential of Bonti-bonti (Paratherina striata Aurich) in Lake Towuti, South Sulawesi. By: Syahroma Husni Nasution, Ismudi Muschsin, and Sulistiono

Bonti-bonti (Paratherina striata), is one of endemic and vulnerable fish in Lake Towuti and Mahalona. Bonti-bonti have been utilized by people around the lake as consumption fish; ornamental fish and as raw material for animal feed. The population tend to decrease due to environmental quality deterioration and increasing exploitation. This study was aimed to reveal the recruit potential of bontibonti as the foundation for its management. This research was conducted in Lake Towuti, South Sulawesi from May 2006 to April 2007. Samples were collected monthly at five stations (Tanjung Bakara; Inlet of Lake Towuti; Pulau Loeha; Outlet of Lake Towuti, and Beau) using experimental gillnet sized $0.625,0.75,1.0$, and 1.25 inches. Recruitment potential could be evaluated from sex ratio, egg diameter, fecundity, and gonad maturity index. Total sex ratio of male and female bonti-bonti are 1.0:0.9. Fecundity of bonti-bonti are 818-6.051. Egg diameter of bonti-bonti range from 0.01-1.50 $\mathrm{mm}$. Gonad maturity index value of male and female was found highest at station II (inlet of Lake Towuti) as high as 3.96 and $6.77 \%$ respectively. Based on fecundity, recruitment potential of bontibonti is higher compared to the other Telmatherinid. Temporally, the average value of gonad maturity index was found highest on male in May and November with the values of $2.09 \pm 1.36 \%$ and $1.85 \pm 1.06 \%$, and for female with the values of $3.39 \pm 1.47$ and $3.47 \pm 1.37 \%$. Fish recruitment occured each month with the highest period occur in October-November.

KEYWORDS: recruitment potential, sex ratio, fecundity, Paratherina striata, Lake Towuti 


\section{PENDAHULUAN}

Danau Towuti mempunyai luas $560 \mathrm{~km}^{2}$, kedalaman maksimum $203 \mathrm{~m}$, ketinggian dari permukaan laut $293 \mathrm{~m}$, dan transparansi sedalam 22 $\mathrm{m}$ (Fernando dalam Haffner et al., 2001). Danau Towuti merupakan danau tipe tektonik yang dikelilingi oleh hutan-hutan lebat. Di tengah danau terdapat beberapa pulau, yang terbesar adalah Pulau Loeha yang tidak ada penghuninya.

Ikan bonti-bonti adalah salah satu dari empat jenis ikan Paratherina yang endemik dan statusnya rawan punah (vulnerable species) (IUCN, 2003; Froese \& Pauly, 2004). Ikan ini hanya terdapat di Danau Towuti dan Danau Mahalona, Sulawesi Selatan (Kottelat et al., 1993; Wirjoatmodjo et al., 2003). Ikan ini merupakan bagian dari kekayaan sumber daya hayati dan plasma nutfah, namun pemerintah belum melindungi ikan tersebut. Masyarakat di sekitar danau memanfaatkan ikan ini sebagai ikan konsumsi dalam bentuk kering atau asin maupun sebagai ikan hias dan bahan pakan hewan (Nasution, 2006).

Diperkirakan potensi kemampuan pulih kembali populasi ikan ini mengalami penurunan. Penurunan daya pulih terkait dengan adanya dugaan bahwa potensi pertumbuhan dan rekrutmen yang cenderung menurun. Menurut Reid \& Miller (1989) menurunnya stok ikan air tawar sebagian besar disebabkan oleh kerusakan atau lenyapnya habitat (35\%), introduksi spesies eksotik (30\%), dan eksploitasi spesies yang berlebihan (4\%). Sisanya (31\%), karena pencemaran, persaingan penggunaan air dan pemanasan global.

Informasi mengenai ikan bonti-bonti terbatas pada sistematika (Weber \& De Beaufort, 1922; Kottelat et al., 1993) dan distribusinya (Wirjoatmodjo et al., 2003), sedangkan informasi mengenai rekrutmen dan potensi rekrut ikan ini belum diketahui.

Penelitian ini bertujuan untuk mengkaji potensi rekrut ikan bonti-bonti dalam rangka melindungi populasinya agar tetap tinggi dan lestari. Hal ini dapat menggambarkan kondisi populasi ikan tersebut di alam dan dapat digunakan sebagai informasi dan dasar untuk merumuskan kebijakan pengelolaan sumber daya ikan bonti-bonti di Danau Towuti.

\section{BAHAN DAN METODE}

\section{Tempat dan Waktu Penelitian}

Penelitian dilakukan di perairan Danau Towuti, Kabupaten Luwu Timur, Sulawesi Selatan. Pengamatan dilakukan setiap bulan secara periodik selama 12 bulan dari bulan Mei 2006-April 2007. Pengambilan contoh ikan dan data lingkungan atau habitat dilakukan setiap periode pengambilan contoh. Analisis contoh dilakukan di Laboratorium Biologi Perairan Pusat Penelitian Limnologi-Lembaga IImu Pengetahuan Indonesia, Cibinong.

\section{Metode}

Metode penelitian yang digunakan adalah metode deskriptif. Pemilihan stasiun pengambilan contoh dilakukan dengan mempertimbangkan tipologi habitat, pengaruh atau tekanan lingkungan sekitar danau dan eksploitasi. Penentuan posisi stasiun penelitian menggunakan global positioning system. Deskripsi dan posisi lima stasiun pengambilan contoh dalam studi ini dilihat pada Tabel 1 dan Gambar 1.

\section{Metode Pengukuran}

Data tinggi muka air Danau Towuti, diperoleh dari PT. INCO. Contoh ikan ditangkap menggunakan experimental gillnet dengan ukuran mata jaring 0,625 , $0,75,1,0$, dan 1,25 inci. Panjang tiap ukuran mata jaring masing-masing $50 \mathrm{~m}$ dan tinggi $2 \mathrm{~m}$, sehingga panjang total jaring satu unit adalah $200 \mathrm{~m}$. Satu unit jaring dioperasikan dengan cara dibentangkan membentuk sudut $45-90^{\circ}$ terhadap garis pantai yang dipasang di setiap stasiun selama lebih kurang 15 jam.

Data kelimpahan relatif ikan diperoleh dengan menghitung jumlah dan mencatat ukuran ikan yang diperoleh dari hasil pengoperasian experimental gillnet. Contoh ikan diawetkan dalam formalin $4 \%$, selanjutnya direndam dalam larutan alkohol $70 \%$. Di laboratorium, panjang ikan diukur menggunakan jangka sorong dengan ketelitian $0,5 \mathrm{~mm}$. Bobot tubuh dan gonad diukur menggunakan timbangan analitik dengan ketelitian 0,001 g. Selanjutnya ikan dipisahkan menurut jenis kelamin dan ukuran panjang, kemudian ikan dibedah. Jenis kelamin ikan diketahui dengan melihat tanda seksual primer (gonad) dan seksual sekunder seperti warna tubuh dan keadaan siripnya. 
Tabel 1. Stasiun pengamatan dan titik koordinat

Table 1. Research station and coordinate point

\begin{tabular}{|c|c|c|c|}
\hline \multicolumn{2}{|r|}{ Stasiun nama stasiun penelitian } & Deskripsi & Titik koordinat \\
\hline $\mathrm{I}$. & Tanjung Bakara & $\begin{array}{l}\text { Terdapat pengaruh aktivitas penggergajian } \\
\text { kayu dan kegiatan penduduk yang tinggi } \\
\text { dalam bidang perikanan. Substrat terdiri atas } \\
\text { batu, pasir, dan lumpur. }\end{array}$ & $\begin{array}{l}02^{\circ} 40^{\prime} 47,1^{\prime \prime} \mathrm{LS} \\
121^{\circ} 25^{\prime} 04,0^{\prime \prime} \mathrm{BT}\end{array}$ \\
\hline 11. & $\begin{array}{l}\text { Inlet Danau Towuti yang berasal } \\
\text { dari Sungai Tominanga }\end{array}$ & $\begin{array}{l}\text { Substrat terdiri atas batu, kerikil dan pasir, } \\
\text { serta jauh dari tempat tinggal penduduk. }\end{array}$ & $\begin{array}{l}02^{\circ} 39^{\prime} 43,4^{\prime \prime} \mathrm{LS} \\
121^{\circ} 32^{\prime} 46,0^{\prime \prime} \mathrm{BT}\end{array}$ \\
\hline III. & Pulau Loeha & $\begin{array}{l}\text { Terletak di tengah danau dan tidak dihuni } \\
\text { oleh penduduk. Substrat terdiri atas batu, } \\
\text { kerikil, dan pasir. }\end{array}$ & $\begin{array}{l}02^{\circ} 44^{\prime} 33,9^{\prime \prime} \mathrm{LS} \\
121^{\circ} 34^{\prime} 44,6^{\prime \prime} \mathrm{BT}\end{array}$ \\
\hline IV. & $\begin{array}{l}\text { Outlet Danau Towuti yang } \\
\text { mengalir ke Sungai Larona }\end{array}$ & $\begin{array}{l}\text { Substrat terdiri atas batu dan lumpur, terdapat } \\
\text { tanaman air serta jauh dari tempat tinggal } \\
\text { penduduk. }\end{array}$ & $\begin{array}{l}02^{\circ} 47^{\prime} 35,1^{\prime \prime} \mathrm{LS} \\
121^{\circ} 24^{\prime} 21,1^{\prime \prime} \mathrm{BT}\end{array}$ \\
\hline V. & Beau & $\begin{array}{l}\text { Terletak di daerah dengan pengaruh aktivitas } \\
\text { penduduk yang tinggi dalam bidang } \\
\text { perikanan. Substrat terdiri atas lumpur } \\
\text { berpasir dan banyak terdapat tanaman air. }\end{array}$ & $\begin{array}{l}02^{\circ} 51^{\prime} 23,2^{\prime \prime L S} \\
121^{\circ} 32^{\prime} 46,6^{\prime \prime B T}\end{array}$ \\
\hline
\end{tabular}

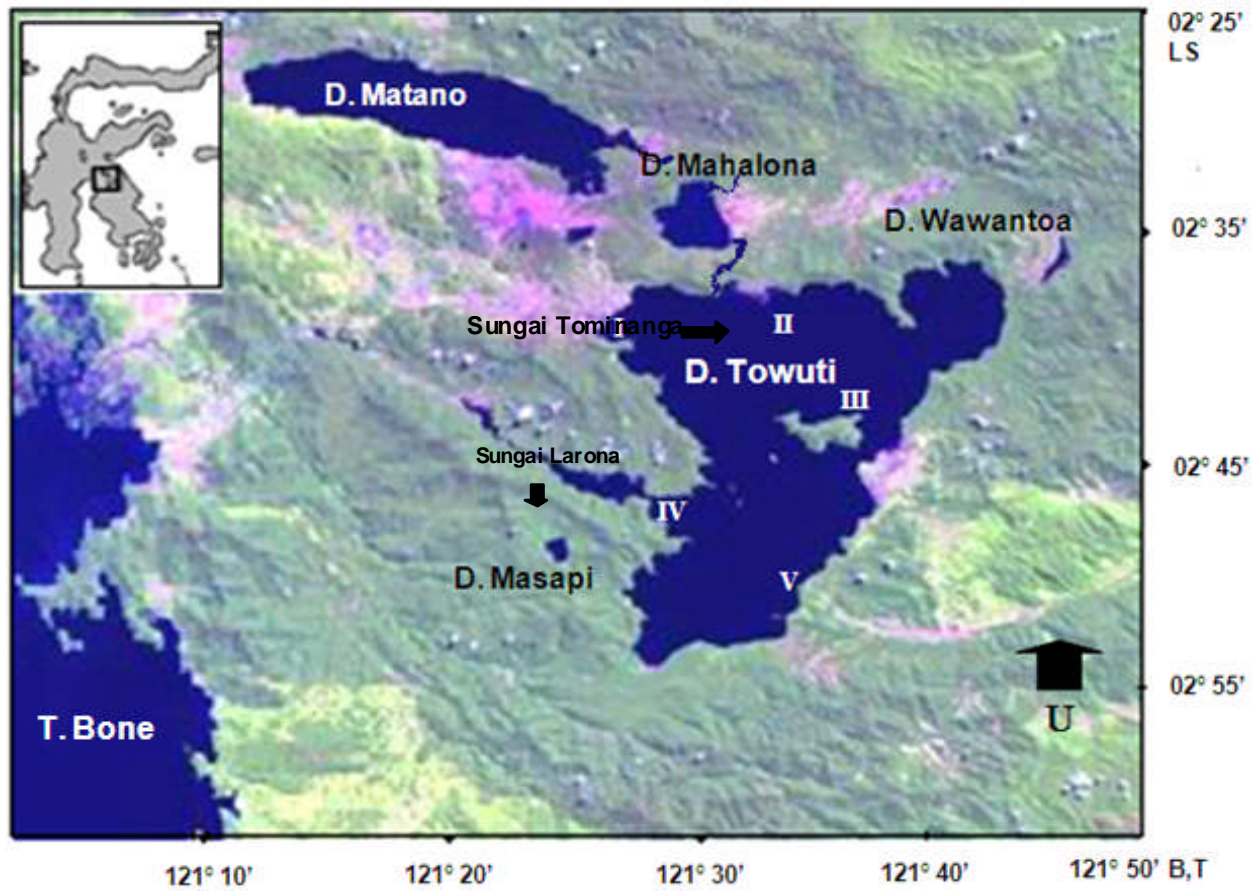

Keterangan/Remarks: I-V = stasiun penelitian

Gambar 1. Stasiun pengambilan contoh di Danau Towuti. Sumber: Modifikasi dari Hehanussa (2006)

Figure 1. Sampling station in Lake Towuti. Source: Modified from Hehanussa (2006) 
Tingkat kematangan gonad ikan dilihat secara histologis dengan teknik pewarnaan yang mengacu pada Kiernan (1990). Fekunditas ikan diketahui dengan menghitung jumlah telur pada ikan yang telah matang gonad (tingkat kematangan gonad IV). Telur diawetkan dalam larutan Gilson, kemudian dihitung jumlahnya dengan metode gravimetrik. Contoh ikan diambil sekurang-kurangnya 30 ekor untuk setiap hasil tangkapan tiap periode pengambilan contoh. Diameter telur ikan dapat diketahui dengan cara mengambil masing-masing 100 butir telur dari ikan yang berada pada tingkat kematangan gonad I, II, III, IV, dan V sekurang-kurangnya 30 ekor contoh per tingkat kematangan gonad dari hasil tangkapan tiap periode pengambilan contoh. Diameter telur diamati menggunakan mikroskop yang dilengkapi dengan mikrometer okuler.

\section{Analisis Data}

Potensi rekrut ikan dilihat dari nisbah kelamin (Ball \& Rao, 1984; Purwanto et al., 1986), fekunditas, diameter telur dan indeks kematangan gonad (Trippel et al., 1997). Nisbah kelamin yaitu perbandingan antara jumlah total ikan jantan dan betina yang terdapat pada setiap stasiun dihitung dengan menggunakan rumus:

$$
X=\frac{M}{F}
$$

di mana:

$$
\begin{aligned}
& X=\text { nisbah kelamin } \\
& M=\text { jumlah ikan jantan (ekor) } \\
& F=\text { jumlah ikan betina (ekor) }
\end{aligned}
$$

Indeks kematangan gonad ditentukan dengan menggunakan rumus yaitu:

$$
I K G=\frac{B G}{B T} \times 100 \%
$$

$$
\begin{aligned}
& \text { di mana: } \\
& \text { IKG = indeks kematangan gonad (\%) } \\
& \mathrm{BG}=\text { bobot gonad }(\mathrm{g}) \\
& \mathrm{BT}=\text { bobot tubuh }(\mathrm{g})
\end{aligned}
$$

Nilai indeks kematangan gonad ikan antar stasiun atau habitat dan antar waktu atau musim, dianalisis secara non parametrik Mann-Whitney Test menggunakan perangkat lunak Minitab dan Steel \& Torrie (1981).

Hubungan fekunditas dengan ukuran ikan (panjang dan bobot) ditentukan menggunakan analisis regresi
(Steel \& Torrie, 1981). Contoh telur yang diukur, dibuat frekuensi diameter telurnya. Sebaran diameter telur ikan pada tingkat kematangan gonad III dan IV dianalisis dengan metode Model progression analysis Bhattacharya menggunakan perangkat lunak FiSAT II. Analisis pola rekrutmen/R (penambahan baru) menggunakan perangkat lunak FiSAT II.

\section{HASIL DAN BAHASAN}

\section{Rekrutmen (Penambahan Baru)}

Rekrutmen diartikan sebagai penambahan stok baru (dari semua ukuran) ke dalam populasi (Spare \& Venema, 1998). Berdasarkan pada analisis data panjang total ikan bonti-bonti didapatkan bahwa rekruitmen stok ikan bonti-bonti (gabungan jantan dan betina) terjadi setiap bulan, sedangkan puncaknya diperkirakan pada periode bulan Oktober-Nopember (Gambar 2).

Keberhasilan rekruitmen ikan bonti-bonti pada periode bulan Oktober-Nopember terjadi pada saat tinggi muka air Danau Towuti terus turun dan mencapai titik terendah di bulan Nopember (Gambar 3). Keberhasilan rekruitmen dari hasil pemijahan akan mempengaruhi kelimpahan ikan pada periode selanjutnya. Pola rekruitmen pada ikan bonti-bonti terkait erat dengan fluktuasi tinggi muka air. Nasution (2008) mengatakan bahwa faktor lingkungan yang sangat berpengaruh terhadap kelimpahan ikan bontibonti adalah oksigen terlarut dan tinggi muka air. Berdasarkan pada perhitungan rumus pertumbuhan Von Bertalanffy, umur ikan yang mendominansi pada bulan Nopember dan Desember berkisar antara 1-2 bulan (Nasution, 2008). Dengan demikian kurva penambahan baru ikan bonti-bonti tersebut dapat dijelaskan dengan menghitung mundur antara 1-2 bulan dari bulan Nopember. Penambahan baru pada bulan Nopember berasal dari periode pemijahan pada bulan September, Oktober, dan Nopember (Gambar 2a), sedangkan penambahan baru ikan pada bulan Desember berasal dari periode pemijahan di bulan Oktober, Nopember, dan Desember (Gambar 2b). Peningkatan komposisi ukuran ikan kecil terdapat pada bulan Nopember, sedangkan pada bulan Oktober komposisi ukuran ikan besar lebih dominan. Pemijahan ikan pada periode bulan SeptemberNopember menghasilkan penambahan baru yang lebih tinggi dibandingkan bulan lain. Lebih lanjut Nasution (2008) mengatakan bahwa keberhasilan pemijahan pada bulan tersebut disebabkan oleh beberapa faktor lingkungan (oksigen terlarut, tinggi muka air, dan ketersediaan makanan) yang dapat memperbesar potensi penambahan baru. 


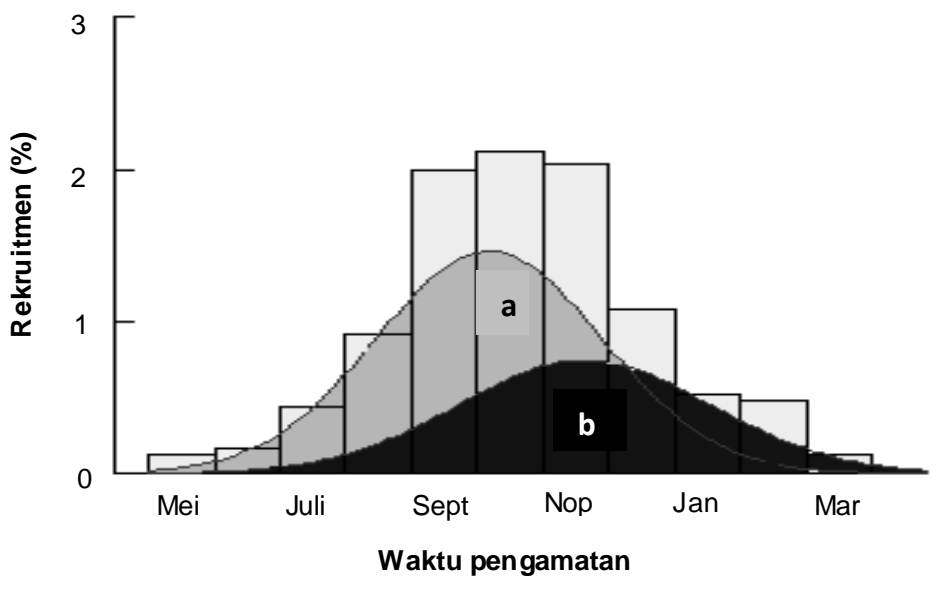

Gambar 2. Rekruitmen ikan bonti-bonti di Danau Towuti dari bulan Mei 2006-April 2007.

Figure 2. Recruitment of bonti-bonti in Lake Towuti from May 2006-April 2007.

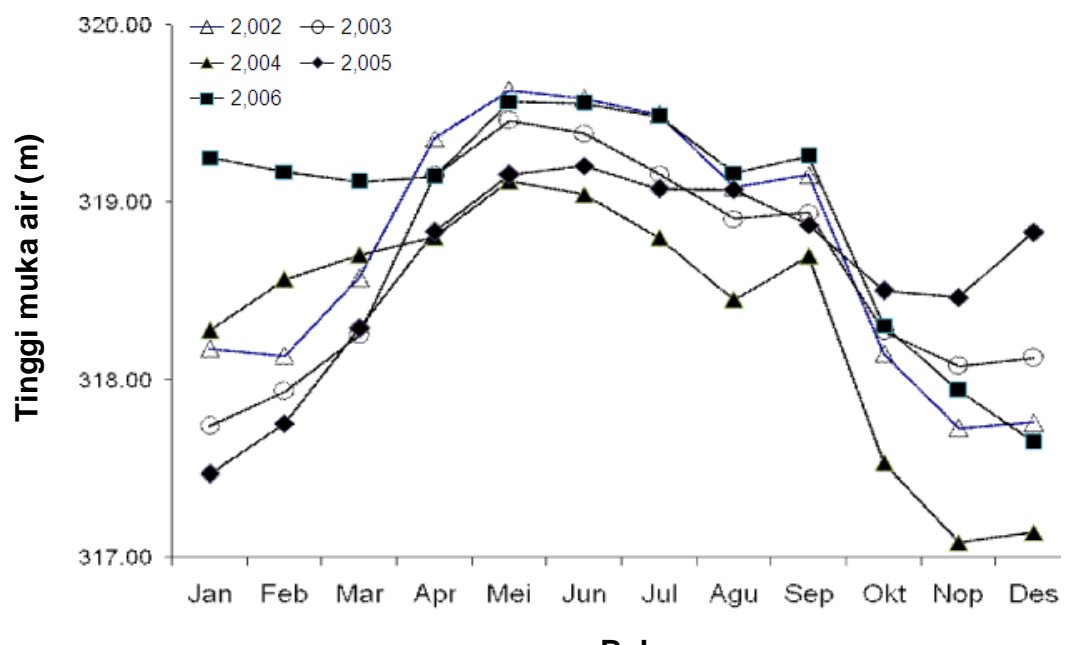

Bulan

Gambar 3. $\quad$ Tinggi muka air Danau Towuti dari tahun 2002-2006.

Figure 3. High water level of Lake Towuti from 2002-2006.

\section{Potensi Rekrut}

\section{Nisbah kelamin}

Nisbah kelamin pada ikan penting diketahui karena berpengaruh terhadap kestabilan populasi ikan tersebut di alam. Dalam suatu populasi apabila nisbah kelamin tidak seimbang, maka perkembangan populasi akan terhambat (rekruitmen mengecil). Nikolsky (1963) mengatakan perbedaan ukuran dan jumlah salah satu jenis kelamin dalam populasi disebabkan adanya perbedaan pola pertumbuhan, perbedaan umur, karena ukuran pertama kali matang gonad, dan adanya penambahan jenis ikan baru pada suatu populasi ikan yang sudah ada.
Gambar 4 memperlihatkan fluktuasi nisbah kelamin ikan bonti-bonti. Nisbah kelamin total ikan bonti-bonti jantan dan betina di Danau Towuti adalah 879:791 atau 1,0:0,9. Berdasarkan pada uji Mann-Whitney, jumlah ikan jantan dan betina tersebut dianggap sama $(\alpha=0,2852)$. Menurut (Ball \& Rao, 1984), nisbah kelamin ikan jantan dan betina dapat dikatakan seimbang 1,0:1,0. Purwanto et al. (1986) mengatakan bahwa untuk mempertahankan populasi maka perbandingan ikan jantan dan betina berada dalam kondisi seimbang. Keseimbangan komposisi ikan jantan dan betina dapat menjaga populasi ikan dari kepunahan. 


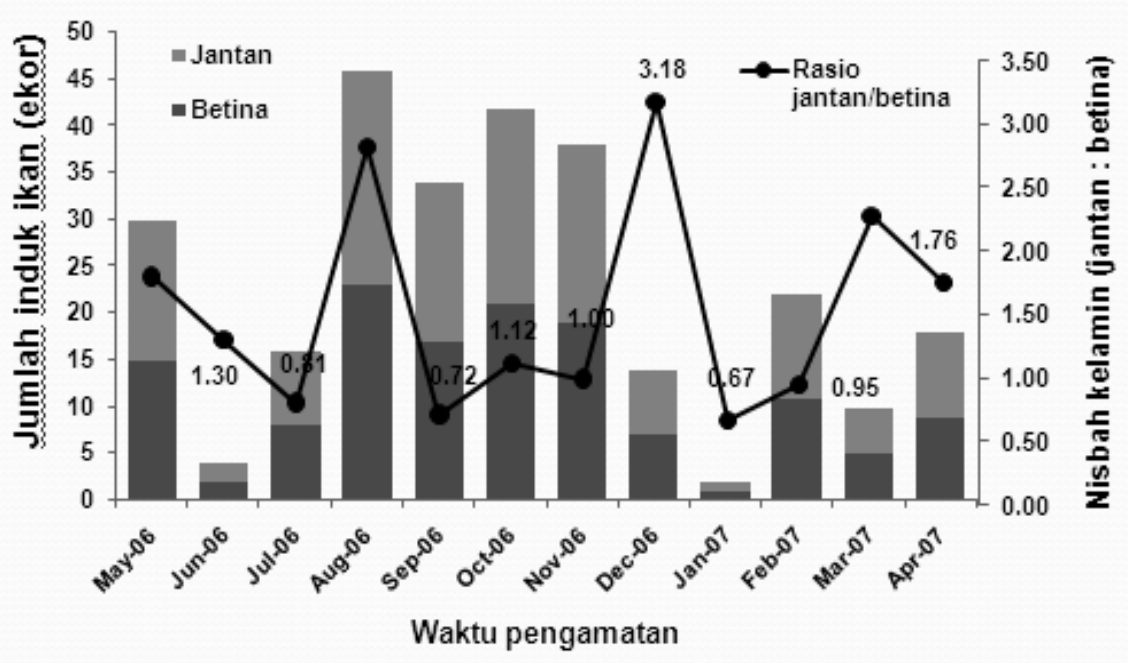

Gambar 4. Nisbah kelamin dan jumlah induk ikan bonti-bonti dari bulan Mei 2006-April 2007.

Figure 4. Sex ratio and brood stock amount of bonti-bonti from May 200-April 2007.

Nisbah kelamin dan komposisi induk ikan bontibonti mendekati satu terjadi pada bulan Oktober dan Nopember masing-masing 1,12 dan 1,00. Pada bulan lainnya nisbah kelamin semakin besar, di mana pada umumnya komposisi ikan jantan lebih banyak dibandingkan ikan betina. Komposisi ikan jantan dan betina dapat dijadikan indikator keberhasilan rekruitmen.

Nisbah kelamin dipengaruhi oleh tingkah laku pemijahan masing-masing jenis ikan. Gray \& McKinnon (2006) mengatakan pada kelompok ikan dari famili Telmatherinidae seperti Tominanga sp. dan Tominanga sarasinorum, tiap pasangan ikan terdiri atas 3-7 ekor ikan jantan dan satu ekor ikan betina. Pemijahan dilakukan oleh satu ekor ikan betina dengan 1-2 ekor ikan jantan. Selanjutnya dikatakan seringkali terjadi perkelahian untuk memperebutkan ikan betina oleh pejantan lain (penyelinap atau sneaker). Pejantan penyelinap di samping menimbulkan persaingan, dicurigai melakukan tindakan kanibal terhadap telur ikan sejenis. Gray \& McKinnon (2006) mengatakan pula bahwa aktivitas kanibalisme telur terjadi pada ikan T. sarasinorum dan Telmatherina celebensis.

Potensi rekrut beberapa jenis ikan Telmatherinidae juga dapat dilihat dari indeks kematangan gonad, diameter telur, dan fekunditas yang ditunjukan pada Tabel 2 dan 3. Dibandingkan ikan Telmatherinidae lain, ukuran tubuh ikan bonti-bonti paling besar. Nilai indeks kematangan gonad ikan bonti-bonti relatif lebih kecil dibandingkan ikan T. ladigesi, T. antoniae, dan $T$. celebensis, namun ukuran panjang ikan bonti-bonti jauh lebih panjang dibandingkan ikan T. ladigesi. Ukuran diameter telur ikan bonti-bonti relatif lebih kecil dibandingkan ikan T. celebensis, T. antoniae, dan T. ladigesi. Hal ini menyebabkan fekunditas ikan bontibonti lebih banyak dibandingkan ikan dari famili Telmatherinidae lain. Apabila dilihat dari fekunditas, potensi rekrut ikan bonti-bonti lebih tinggi dibandingkan ikan dari famili Telmatherinidae lain. Tabel 3 memperlihatkan kondisi ikan bonti-bonti matang secara seksual berada pada tingkat kematangan gonad IV dengan ukuran diameter telur mencapai $1,5 \mathrm{~mm}$.

Tabel2. Potensi rekrut ikan bonti-bonti dibandingkan dengan beberapa jenis ikan dari famili Telmatherinidae lain

Table 2. Recruitment potential of bonti-bonti compared to with a few species from other Telmatherinid

\begin{tabular}{lcccc}
\hline Parameter & P. striata & T. celebensis $^{1)}$ & T. antoniae $^{2}$ ) & T. ladigesi $^{3 \text { ) }}$ \\
\hline Panjang total (cm) & $11,30-18,33$ & $6,39-8,86$ & $8,00-9,60$ & $3,58-4,33$ \\
IKG (\%) & $0,02-6,77$ & $1,87-2,60$ & $0,59-2,63$ & $0,61-8,81$ \\
Diameter telur (mm) & $0,01-1,50$ & $0,02-1,79$ & $0,03-2,02$ & $0,10-1,15$ \\
Fekunditas (butir) & $818-6.051$ & $185-1.448$ & $61-855$ & $88-910$ \\
\hline
\end{tabular}

Sumber/Sources: 1) Nasution (2005); ${ }^{2)}$ Sumassetiyadi (2003; ${ }^{3)}$ Nasution et al. (2006) 
Tabel 3.

Keadaan histologi ovari dan testis ikan bonti-bonti pada masing-masing tingkat perkembangan Table 3. Ovary and testes histology of bonti-bonti from each development stage

\begin{tabular}{|c|c|c|}
\hline Tingkat kematangan gonad & Ovari & Testis \\
\hline I. Belum berkembang & $\begin{array}{l}\text { Ovari belum matang didominansi oleh } \\
\text { oosit stadia I berukuran } 10-700 \mu \mathrm{m} \\
\text { bersifat sangat basofil. Inti berbentuk } \\
\text { bulat atau oval. Sitoplasma lebih tebal, } \\
\text { terdapatbeberapa nukleolus. }\end{array}$ & $\begin{array}{l}\text { Testis didominansi oleh jaringan ikat, } \\
\text { terdapat lobus berbentuk lonjong yang } \\
\text { berisi spematogonia I dan II. Sel } \\
\text { spematogonium berwarna merah } \\
\text { muda. }\end{array}$ \\
\hline II. Perkembangan awal & $\begin{array}{l}\text { Ovari dipenuhi oosit bernukeus besar } \\
\text { (oosit stadia I dan II), terdapat vakuola } \\
\text { pada perifer. Oosit berukuran } 10-880 \\
\mu \mathrm{m} \text {. Oosit yang belum matang } \\
\text { sitoplasmanya berwarna ungu, } \\
\text { sedangkan yang sudah matang } \\
\text { berwarnamerahmuda. }\end{array}$ & $\begin{array}{l}\text { Testis telah berkembang, jaringan ikat } \\
\text { semakin sedikit. Lobus didominansi } \\
\text { oleh spematogonia stadia II, terdapat } \\
\text { beberapa spematogonia I dan } \\
\text { spermatositprimer. }\end{array}$ \\
\hline III. Sedang berkembang & $\begin{array}{l}\text { Oosit berukuran } 30-1.300 \mu \mathrm{m} \text {. Oosit } \\
\text { stadia III (ootid) bergranula kuning telur } \\
\text { dimulai dari daerah inti kemudian } \\
\text { menyebar ke tengah dan terdesak ke } \\
\text { tepi. Sitoplasma didominansi globula } \\
\text { lipoprotein. }\end{array}$ & $\begin{array}{l}\text { Spermatosit primer berkembang } \\
\text { menjadi spermatosit sekunder. Lobus } \\
\text { berisi sel-sel spermatosit primer dan } \\
\text { sekunder. Sebagian spermatosit } \\
\text { sekunder berkembang menjadi } \\
\text { spermatid. }\end{array}$ \\
\hline IV. Matang & $\begin{array}{l}\text { Oosit berukuran } 30-1.500 \text { um. Oosit } \\
\text { stadia IV (ovum) adalah oossit tertua } \\
\text { yang ditandai dengan berakhirnya } \\
\text { pembentukan kuning telur. Oosit dengan } \\
\text { sitoplasma yang berisi vakuola-vakuola } \\
\text { lipoprotein berukuran besar. Oosit ini } \\
\text { siap diovulasikan. Di samping oosit } \\
\text { stadia IV terdapat pula oosit stadia I, II, } \\
\text { dan III. }\end{array}$ & $\begin{array}{l}\text { Spermatid berkembang menjadi } \\
\text { spermatozoa. Lobus penuh dengan } \\
\text { spermatid dan spermatozoa. }\end{array}$ \\
\hline V. Pasca pemijahan & $\begin{array}{l}\text { Bentuk oosit berbeda dengan oosit } \\
\text { stadia IV. Dinding folikel berkerut-kerut. } \\
\text { Jumlah oosit stadia IV sedikit, } \\
\text { didominansi oleh oosit stadia I, II, dan III. } \\
\text { Sebagian daerah ovari kosong. }\end{array}$ & $\begin{array}{l}\text { Secara umum, tingkat kematangan } \\
\text { gonad } V \text { ini hampir sama dengan } \\
\text { tingkat kematangan gonad IV, } \\
\text { spermatogonium sudah terlihat lagi, } \\
\text { lobus mengkerut. }\end{array}$ \\
\hline
\end{tabular}

Menurut Moyle \& Joseph (1988) ada dua strategi dasar reproduksi pada ikan yaitu semelparity adalah ikan memijahkan telur secara total dalam jumlah besar kemudian mati dan iteroparity adalah ikan memijahkan telur secara berulang-ulang sepanjang tahun akibat kondisi lingkungan yang tidak terduga sehingga tidak ada jaminan larva dapat bertahan pada kondisi lingkungan saat musim pemijahan. Berdasarkan pada strategi reproduksi tersebut, ikan bonti-bonti termasuk ikan yang memiliki strategi reproduksi iteroparity yang memijah sepanjang tahun, sehingga rekruitmen atau penambahan baru ikan bonti-bonti dapat terjadi sepanjang tahun. Pemijahan ikan bonti-bonti di Danau Towuti erat kaitannya dengan kondisi lingkungan seperti tinggi muka air (Nasution, 2008). Berdasarkan pada nilai indeks kematangan gonad rata-rata tiap bulan, diperkirakan puncak pemijahan terjadi sekitar bulan Mei dan Nopember.

\section{Fekunditas}

Fekunditas adalah jumlah telur pada ikan betina sebelum dikeluarkan pada waktu akan memijah. Fekunditas mempunyai keterkaitan dengan umur, panjang atau bobot individu, dan spesies ikan (Effendie, 1979). Fekunditas ikan bonti-bonti dengan ukuran panjang total antara $11,30-18,33 \mathrm{~cm}$ dan bobot total antara 14,00-77,52 g sebanyak 818-6.051 butir (rata-rata $3.154 \pm 1.318$ butir). Hubungan antara fekunditas dengan panjang dan bobot total ikan bontibonti ditentukan dengan masing-masing persamaan adalah $\mathrm{F}=0,704 \mathrm{PT}^{3,220}(\mathrm{r}=0,74)$ dan $\mathrm{F}=118,815 \mathrm{BT}^{1,003}$ $(r=0,76)$. 
Fekunditas ikan bonti-bonti paling banyak (8186.051 butir) dibandingkan ikan T. ladigesi, T. antoniae, dan $T$. celebensis (Tabel 2). Fekunditas ikan $T$. celebensis pada kisaran panjang total $6,39-8,86 \mathrm{~cm}$ dengan bobot total 2,75-9,60 $\mathrm{g}$ berjumlah antara 1851.448 butir (Nasution, 2005). Hal ini karena di samping ukuran tubuh ikan bonti-bonti relatif lebih besar (panjang 18,33 cm dan bobot 77,52 g), ukuran telur ikan bonti-bonti $(0,01-1,50 \mathrm{~mm})$ juga relatif lebih kecil dibandingkan ikan $T$. celebensis $(0,02-1,79 \mathrm{~mm})$.

\section{Diameter telur}

Diameter telur ikan bonti-bonti berkisar antara 0,01$1,50 \mathrm{~mm}$. Antara tingkat kematangan gonad I dan III (belum matang gonad) terdapat dua kelas ukuran diameter telur dengan frekuensi relatif tinggi, yaitu telur berdiameter 0,01-0,16 mm (56\%) dan 0,46-0,60 mm (11\%). Antara tingkat kematangan gonad IV dan V (matang gonad) terdapat tiga buah kelas ukuran diameter telur, yaitu telur berdiameter $0,01-0,16 \mathrm{~mm}$ (14\%), 0,46-0,60 mm (19\%), dan 0,91-1,05 mm (14\%).

Sebaran diameter telur ikan bonti-bonti pada tingkat kematangan gonad III dan IV, menunjukan bahwa terdapat tiga kelompok diameter telur (Gambar 5). Kelompok ukuran pertama berdiameter $0,01-0,75$ $\mathrm{mm}$, kedua berdiameter $0,16-0,90 \mathrm{~mm}$, dan ketiga berdiameter 0,60-1,50 mm. Hal ini menunjukan bahwa telur ikan bonti-bonti dalam satu ovari tidak matang serentak. Berdasarkan pada sebaran ukuran diameter telur tersebut, ikan bonti-bonti termasuk ikan yang memijah secara parsial (partial/multiple spawner).

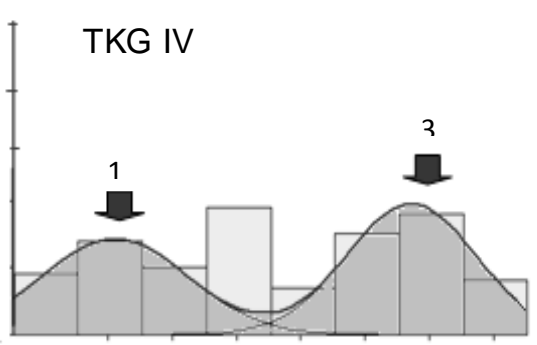

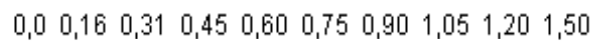

Diameter telur (mm)

Gambar 5. Analisis Bhattacharya pada sebaran ukuran diameter telur ikan bonti-bonti pada tingkat kematangan gonad III dan IV.

Figure 5. Bhattacharya analysis on egg diameter distribution of bonti-bonti at maturity stages of III and IV.

\section{Indeks kematangan gonad}

Untuk mengetahui perubahan gonad secara kuantitatif dapat dikatakan dengan suatu indeks kematangan gonad. Dengan memantau perubahan indeks kematangan gonad dari waktu ke waktu maka dapat diketahui ukuran ikan mulai memijah. Nilai maksimal indeks kematangan gonad ikan bonti-bonti jantan dan betina paling tinggi dijumpai di stasiun II (inlet Danau Towuti) yaitu masing-masing 3,96 dan 6,77\% (Tabel 4). Nilai rata-rata indeks kematangan gonad ikan jantan antar stasiun pengamatan berdasarkan pada uji Mann-Whitney tidak berbeda nyata (á $>0,050$ ), kecuali di stasiun IV. Nilai rata-rata indeks kematangan gonad ikan jantan di stasiun IV paling rendah $(0,27 \%)$. Pada ikan betina, nilai rata-rata indeks kematangan gonad paling tinggi dijumpai di stasiun II dan III (1,70 dan 1,73\%). Nilai indeks kematangan gonad di kedua stasiun tersebut tidak berbeda nyata $(\alpha=0,171)$.

Berdasarkan pada uji Mann-Whitney, nilai rata-rata indeks kematangan gonad ikan jantan dan betina antar stasiun pengamatan tidak berbeda nyata. Hal ini disebabkan karena variasi (ragam) nilai indeks kematangan gonad cukup tinggi baik pada ikan jantan maupun betina. Pernyataan tersebut menunjukan ikan ini dapat memijah hampir di semua stasiun. Namun demikian, stasiun II dan III diduga merupakan tempat pemijahan ikan bonti-bonti di Danau Towuti karena ditemukan ikan dengan nilai indeks kematangan gonad tertinggi baik pada ikan jantan maupun betina dan kemungkinan mikrohabitat di setiap stasiun berbeda. 
Tabel 4. Nilai indeks kematangan gonad ikan bonti-bonti jantan dan betina di setiap stasiun pengambilan contoh di Danau Towuti

Table 4. Gonado somato index value of male and female bonti-bonti in every sampling station in Lake Towuti

\begin{tabular}{ccccccccccc}
\hline \multirow{2}{*}{ Stasiun } & \multicolumn{4}{c}{ IKG Jantan (\%) } & \multicolumn{4}{c}{ IKG Betina (\%) } \\
\cline { 2 - 10 } & N & Min & Maks & $\begin{array}{c}\text { Rata- } \\
\text { rata }\end{array}$ & STDev. & N & Min & Maks & $\begin{array}{c}\text { Rata- } \\
\text { rata }\end{array}$ & STDev. \\
\hline I & 52 & 0,01 & 1,33 & 0,40 & 0,18 & 36 & 0,05 & 4,48 & 1,22 & 0,56 \\
II & 308 & 0,01 & 3,96 & 0,51 & 0,19 & 250 & 0,05 & 6,77 & 1,70 & 0,62 \\
III & 133 & 0,02 & 3,58 & 0,40 & 0,16 & 91 & 0,12 & 4,69 & 1,73 & 0,44 \\
IV & 85 & 0,01 & 0,87 & 0,27 & 0,12 & 123 & 0,02 & 5,33 & 1,23 & 0,56 \\
V & 15 & 0,01 & 1,15 & 0,43 & 0,18 & 22 & 0,15 & 4,46 & 1,23 & 0,55 \\
\hline
\end{tabular}

Keterangan/Remarks: I = Tanjung Bakara; II = inlet Danau Towuti; III = Pulau Loeha; IV = outlet Danau Towuti; V = Beau

Secara temporal, nilai rata-rata indeks kematangan gonad tertinggi terjadi dua kali setahun. Patut diduga ikan bonti-bonti melakukan beberapa kali (minimal dua kali) pemijahan dalam setahun. Pada ikan jantan rata-rata indeks kematangan gonad tertinggi ditemukan pada bulan Mei dan Nopember $(2,09 \pm 1,36 \%$ dan $1,85 \pm 1,06 \%)$, sedangkan pada ikan betina rata-rata indeks kematangan gonad tertinggi terjadi pada bulan Mei, Juni, dan Nopember $(3,39 \pm 1,47 ; 3,66 \pm 0,57 \%$, dan $3,47 \pm 1,37 \%$ ) (Gambar $6)$.

Secara temporal, nilai rata-rata indeks kematangan gonad ikan bonti-bonti jantan memiliki nilai tertinggi di bulan Mei dan Nopember. Pada bulan Mei tinggi muka air berada pada level tertinggi dan pada bulan Nopember tinggi muka air mulai meningkat. Berdasarkan pada uji Mann-Whitney menunjukkan bahwa nilai indeks kematangan gonad tersebut berbeda nyata $(\alpha=0,0007)$. Rendahnya nilai rata-rata indeks kematangan gonad ikan jantan di bulan Nopember dibandingkan bulan Mei disebabkan ukuran ikan didominansi oleh ikan kecil $(76 \%$ berukuran $3,80-9,00 \mathrm{~cm}$ dan $24 \%$ berukuran 9,01 $19,78 \mathrm{~cm} ; \mathrm{N}=240$ ekor). Demikian juga nilai rata-rata indeks kematangan gonad ikan bonti-bonti betina secara temporal memiliki nilai tertinggi di bulan Mei, Juni, dan Nopember. Uji Mann-Whitney antara bulan Mei dan Juni menunjukan bahwa nilai tingkat kematangan gonad tersebut tidak berbeda nyata $(\alpha=0,6170)$, sedangkan antara bulan Juni dan Nopember berbeda nyata $(\alpha=0,0547)$.
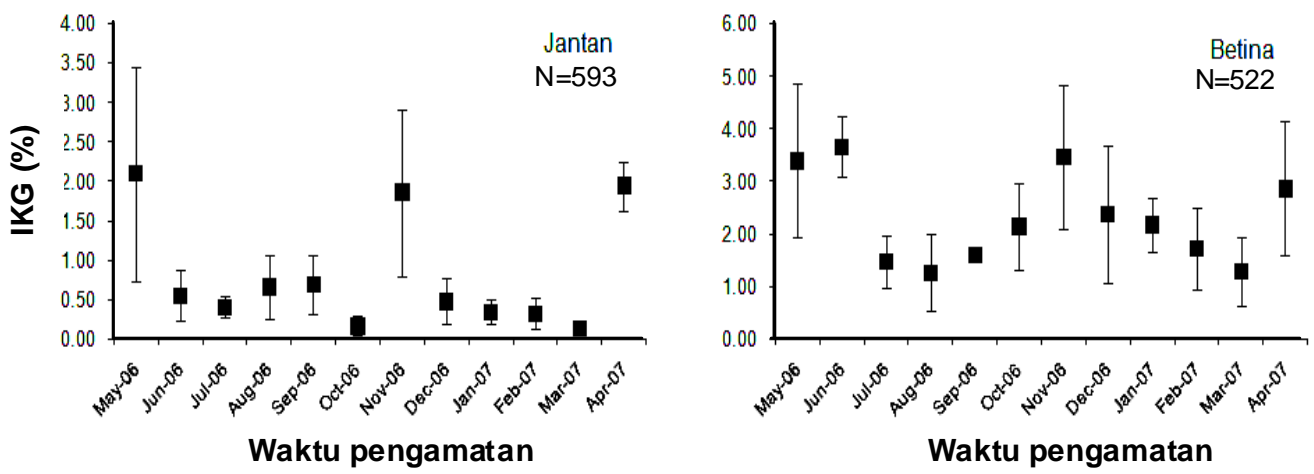

Gambar 6. Nilai rata-rata indeks kematangan gonad ikan bonti-bonti jantan dan betina secara temporal. Figure 6. Average value of gonado somatic index of male and female bonti-bonti by temporal. 
Berdasarkan pada nilai indeks kematangan gonad rata-rata tiap bulan diduga bulan Mei dan Nopember merupakan musim pemijahan ikan bonti-bonti di Danau Towuti. Nasution et al. (2007) mengatakan bahwa pada bulan Nopember ikan T. celebensis dewasa banyak ditemukan dalam kondisi matang gonad. Ikan bonti-bonti melakukan pemijahan beberapa kali di setiap tahunnya. Menurut Bagenal (1978) bahwa ikan betina yang mempunyai nilai indeks kematangan gonad lebih kecil dari $20 \%$ dapat melakukan pemijahan beberapa kali di setiap tahunnya. Dalam penelitian ini nilai indeks kematangan gonad ikan bonti-bonti berkisar 0,01$6,77 \%$. Pada ikan bonti-bonti puncak pemijahannya diperkirakan bulan Nopember, di samping karena nilai indeks kematangan gonad rata-rata yang tinggi juga karena pada bulan tersebut adalah saat awal musim hujan di mana banyak sumber masukan allochthonus (bahan organik yang berasal dari lingkungan di luar sungai atau danau).

\section{KESIMPULAN}

1. Nisbah kelamin total ikan bonti-bonti jantan dan betina adalah 879:791 atau 1,0:0,9. Fekunditas ikan bonti-bonti 818-6.051 butir dan diameter telur ikan bonti-bonti berkisar antara 0,01-1,50 mm.

2. Secara spasial, nilai indeks kematangan gonad ikan bonti-bonti jantan dan betina paling tinggi dijumpai di stasiun II, masing-masing 3,96 dan $6,77 \%$. Ditinjau dari parameter tersebut khususnya fekunditas, potensi rekrut ikan bonti-bonti lebih tinggi dibandingkan ikan Telmatherinidae lain. Secara temporal, nilai rata-rata indeks kematangan gonad tertinggi pada ikan jantan dan betina terjadi pada bulan Mei dan Nopember masing-masing dengan nilai $2,09 \pm 1,36 \%$ dan $1,85 \pm 1,06 \% ; 3,39 \pm 1,47$ dan $3,47 \pm 1,37 \%$.

3. Rekruitmen ikan bonti-bonti terjadi setiap bulan dengan periode tertinggi antara bulan OktoberNopember.

\section{PERSANTUNAN}

Tulisan ini merupakan kontribusi dari kegiatan atas bantuan Lembaga IImu Pengetahuan Indonesia, PT. INCO, dan Yayasan Damandiri, tahun 2006-2007. Penulis mengucapkan terima kasih kepada Prof. Dr. Ir. Dedi Soedharma, DEA dan Dr. Soetikno Wirjoatmodjo yang telah memberikan masukan. Drs. Jefry Jack Mamangkey, M.Si.; Dista Setiana; Siti Aminah yang telah membantu selama penelitian dan Dr. Ir. Dede Irving Hartoto, APU yang telah memberikan saran, masukan, dan referensi yang mendukung.

\section{DAFTAR PUSTAKA}

Bagenal, T. B. 1978. Aspecs of fish fecundity. Ecology of Freshwater Fish Production. Blackwell Scientific Publications. Oxford. 77-101.

Ball, D. V. \& K. V. Rao. 1984. Marine Fisheries. Tata Mc. Graw Hill Publishing Company. Limited. New Delhi. $521 \mathrm{pp}$.

Effendie, M. I. 1979. Metode Biologi Perikanan. Yayasan Dewi Sri. Cetakan I. Bogor. 112 pp.

Froese, R. \& D. Pauly. 2004. Fish base. World Wide Web Electronic Publication. www.fishbase.org, Download on July 6, 2004.

Gray, S. M. \& J. S. McKinnon. 2006. A comparative description of mating behaviour in the endemic telmatherinid fishes of Sulawesi's Malili Lakes. Journal of Biology of Fishes. 75: 471-482.

Haffner, G. D., P. E. Hehanussa, \& D. I. Hartoto. 2001. The Biology and Physical Processes of Large Lakes of Indonesia: Lakes Matano and Towuti. In M. Munawar \& R. E. Hecky (eds.). The Great Lakes of The World (GLOW): Food-web, health, and integrity. Netherlands. 183-192.

Hehanussa, P. 2006. Land-inland water interactions of the Malili Lakes, their characteristics and antropogenic effects. Proceedings International Symposium. The Ecology and Limnology of the Malili Lakes on March 20-22, 2006 in BogorIndonesia. Supported by: PT. INCO Tbk. and Research Center for Limnology, Indonesian Institute of Sciences. 1-4.

IUCN. 2003. 2003 IUCN Redlist of Threatened Species. www.redlist.org. Download on July 16, 2004.

Kiernan, J. A. 1990. Histological and Histochemical Methods. Theory and Practice. $2^{\text {nd }}$ ed. Pergamon Press. Oxford. 433 pp.

Kottelat, M., A. J. Whitten, S. N. Kartikasari, \& S. Wirjoatmodjo. 1993. Ikan Air Tawar Indonesia Bagian Barat dan Sulawesi. Periplus Edition (HK) Ltd. Bekerjasama dengan Proyek EMDI. Kantor Menteri Negara Kependudukan dan Lingkungan Hidup Republik Indonesia, Jakarta. 293 pp.

Moyle, P. B. \& J. C. Joseph. 1988. Fishes, an Introduction to Ichthyology. Prentice Hall. Englewood Cliffs. New Jersey. 559 pp. 
Nasution, S. H. 2005. Karakteristik reproduksi ikan endemik rainbow selebensis (Telmatherina celebensis Boulenger) di Danau Towuti. Jurnal Penelitian Perikanan Indonesia. Edisi Sumber Daya dan Penangkapan. 11 (2): 29-37.

Nasution, S. H. 2006. Pangkilang (Telmatherinidae) ornamental fish: An economic alternative for people around Lake Towuti. Proceedings International Symposium. The Ecology and Limnology of the Malili Lakes on March 20-22, 2006 in BogorIndonesia. Supported by: PT. INCO Tbk. and Research Center for Limnology, Indonesian Institute of Sciences. 39-46.

Nasution, S. H., D. S. Said, Lukman, Triyanto, \& H. Fauzi. 2006. Aspek reproduksi ikan besengbeseng ( Telmatherina ladigesiAhl) dari beberapa sungai di Sulawesi Selatan. Prosiding Seminar Nasional Ikan IV. Tanggal 29-30 Agustus 2006 di Jatiluhur. 83-93.

Nasution, S. H., Sulistiono, D. S. Sjafei, \& G. S. Haryani. 2007. Distribusi spasial dan temporal ikan endemik Rainbow Selebensis (Telmatherina celebensis Boulenger) di Danau Towuti, Sulawesi Selatan. Jurnal Penelitian Perikanan Indonesia. Edisi Sumber Daya dan Penangkapan. 13 (2): 95104.

Nasution, S. H. 2008. Distribusi spasial dan temporal ikan endemik bonti-bonti (Paratherina striata) di Danau Towuti, Sulawesi Selatan. Jurnal Biologi Indonesia. V (1): 91-104.

Nikolsky, G. V. 1963. The Ecology of Fishes. Academy Press. New York. 432 pp.

Purwanto, G., W. M. Bob, \& S. J. Bustaman. 1986. Studi pendahuluan keadaan reproduksi dan perbandingan kelamin ikan cakalang (Katsuwonus pelamis) di perairan sekitar Teluk Piru dan Elpaputih Pulau Seram. Jurnal Penelitian Perikanan Laut. 34: 67-78.
Reid, W. V. \& K. R. Miller. 1989. Keeping Option Alive: The Scientific Basis for Conserving Biodiversity. World Recources Institute. Washington D. C. 128 pp.

Sparre, P. \& S. C. Venema. 1998. Introduksi pengkajian stok ikan tropis. Badan Penelitian dan pengembangan Perikanan. Terjemahan dari Introduction to Tropical Fish Stock Assessment. FAO Fish Tech. Paper. 306 (1): 376 pp.

Steel, R. G. D. \& J. H. Torrie. 1981. Principles and Procedure of Statistic. Second Edition. Mic Graw Hill Book Company. Inc New York. 748 pp.

Sumassetiyadi, M. A. 2003. Beberapa Aspek Reproduksi Ikan Opudi (Telmatherina antoniae) di Danau Matano Sulawesi Selatan. Program Studi Manajemen Sumber Daya Perairan. Fakultas Perikanan dan IImu Kelautan. Institut Pertanian Bogor. $55 \mathrm{pp}$.

Trippel, E. A., O. S. Kjesbu, \& P. Solemial. 1997. Effects of adult age and size structure on reproductive output in marine fishes. In $\mathrm{R}$. Christopher Chambers \& Edward A. Trippel (eds.). Early life history and recruitment in fish populations. Fish and Fisheries Series 21. Chapman and Hall. 31-62.

Weber, M. \& De Beaufort. 1922. The Fishes of the Indo Australian Archipelago. Vol. IV. E.J. Brill. Leiden. $235 \mathrm{pp}$.

Wirjoatmodjo, S., Sulistiono, M. F. Rahardjo, I. S. Suwelo, \& R. K. Hadiyati. 2003. Ecological Distribution of Endemic Fish Species in Lakes Poso and Malili Complex, Sulawesi Island. Funded by Asean Regional Centre for Biodiversity Conservation and the European Comission. 30 pp. 